Organizations in Society 


\section{ORGANIZATIONS IN SOCIETY}

Glenn Morgan

Macmillan Education 
(C) Glenn Morgan 1990

Softcover reprint of the hardcover 1st edition 1990

All rights reserved. For information, write:

Scholarly and Reference Division,

St. Martin's Press, Inc., 175 Fifth Avenue,

New York, N.Y. 10010

First published in the United States of America in 1990

ISBN 978-0-333-43855-8 ISBN 978-1-349-20779-4 (eBook)

DOI 10.1007/978-1-349-20779-4

Library of Congress Cataloging-in-Publication Data

Morgan, Glenn.

Organizations in society/Glenn Morgan.

p. cm.

Includes bibliographical references.

1. Organization. 2. Organizational behaviour. I. Title HM131.M644 1990

$302.3^{\prime} 5-\mathrm{dc} 20$

89-70084

CIP 
For my mother 


\section{Contents}

Preface ix

Introduction 1

1 Work in Organizations 17

2 Management and Bureaucracy in Organizations 63

3 Rational Calculation, Professional Power and the Managerial Division of Labour 94

4 Rationalization and Institutionalization in the $\begin{array}{ll}\text { State and Civil Society } & 121\end{array}$

5 Organizations and Environments 155

6 Organizations in and across Societies 195

7 Conclusion: Organizational Futures,
Organizational Dilemmas

Bibliography 254

Index 274 


\section{Preface}

This book has been a long time in the making. It derives essentially from ten years' experience of teaching courses on the BA in Organization Studies at Bradford and Ilkley Community College. My first debt, then, is to all the students at Bradford who have had to listen and struggle to understand the early formulation of these ideas. My period at Bradford has also been noteworthy for the opportunity to work with people from a wide variety of disciplinary backgrounds. In particular, I would like to thank the following for their friendship and intellectual support over many years: David Hooper, Tom Johnston, Albert Mills and Liz Shorrocks.

This book would probably still not be finished if I had not been granted a year's study leave by the Governors of Bradford and Ilkley College in 1987-8, and for that reason I owe them a debt of gratitude. In relation to this, I would like to thank Professor David Hickson of the Management Centre at the University of Bradford who helped me get study leave by arranging for me to be a Visiting Fellow at the Management Centre during this period.

David Dunkerley in his role both as External Examiner for the BA in Organization Studies and as reader of this book has been a continuous source of help and encouragement.

Finally, my thanks go to Susan, Ryan, Spencer and Kate for all they have endured over the time of writing this book. 